\title{
Response of Curlleaf Mountain Mahogany to Pruning Treatments in Northern Utah
}

\author{
DENNIS D. AUSTIN AND PHILIP J. URNESS
}

\begin{abstract}
Production of curlleaf mountain mahogany (Cercocarpus ledifolius) within browsing height of big game on winter ranges was increased $500-900 \%$ when $\mathbf{9 0 - 9 9 \%}$ of the canopy was pruned from mature trees. However, since adventitious sprouting did not occur, numerous live twigs must be present in the browsing zone before treatment for any practical benefit to accrue. Pruning at less than 90\% canopy removal and girdling showed positive but smaller vegetative responses, while $100 \%$ canopy removal and application of pruning paint to wound surfaces in an attempt to eliminate sap flow had no effect on forage production available to big game.
\end{abstract}

Improvement of the forage resource on big game winter range is one method to compensate partially for past and present reductions in habitat caused by human encroachment. Improvement can be via range restoration through reductions of competing low-value vegetation and reseeding, or improvement of existing, on-site conditions through intensified management. Methods found to increase the forage yield of desirable range plants become potential management tools (Plummer et al. 1968).

Curlleaf mountain mahogany (Cercocarpus ledifolius) occurs throughout most of the Intermountain Area as part of the mountain brush zone. It is usually associated with true mountain mahogany (Cercocarpus montanus) at lower elevations and often grades into Douglas-fir (Pseudotsuga menziesii). When foliage is within the browsing reach of deer and elk, intensive utilization reduces available forage by shifting the competitive growth advantage to the upper unused portions. It has been shown to be high in nutritive value (Smith 1952; Bissell and Strong 1955), palatability (Smith 1950; Hoskins and Dalke 1955), digestibility (Smith 1957a), and dietary importance (Mitchell 1951; Smith and Hubbard 1954). Unfortunately, in many mature stands, most of the production is unavailable except through occasional snow or wind breakage of limbs. Thus a practical means of reducing canopy height while retaining productivity of these low trees could be highly beneficial to big game.

Revegetation with curlleaf mountain mahogany is generally impractical because of low seed viability (Young et al. 1978), poor seedling survival (Holmgren 1954) even with hand-planted nursery stock (Brown and Martinson 1959), and slow growth (Plummer et al. 1957). Likewise, bulldozing of mature trees has been unsuccessful due to high mortality (Dealy 1971). Pruning has been found to stimulate vegetative growth in many shrubby species (Ferguson and

Authors are wildlife biologist and associate professor, Department of Range Science, Utah State University, Logan, Utah 84322

This study was partially supported by funds from the Pittman Robertson Act under Utah Division of Wildlife Resources Project W105R

Manuscript received March 8, 1979
Basil 1966; Plummer 1974), with variable success for curlleaf mountain mahogany (Smith 1957b; Phillips 1970); Thompson 1970). In summary, a successful methodology has not yet been defined, nor has the magnitude of change in available production been determined under various intensities and methods of treatment. These were the objectives of this study.

\section{Study Area}

During winter 1975-76, four study sites were selected in northern Utah; two were on a lower deer winter range $(1,650$ and $1,820 \mathrm{~m})$, one on upper winter range $(2,000 \mathrm{~m})$, and one on summer range

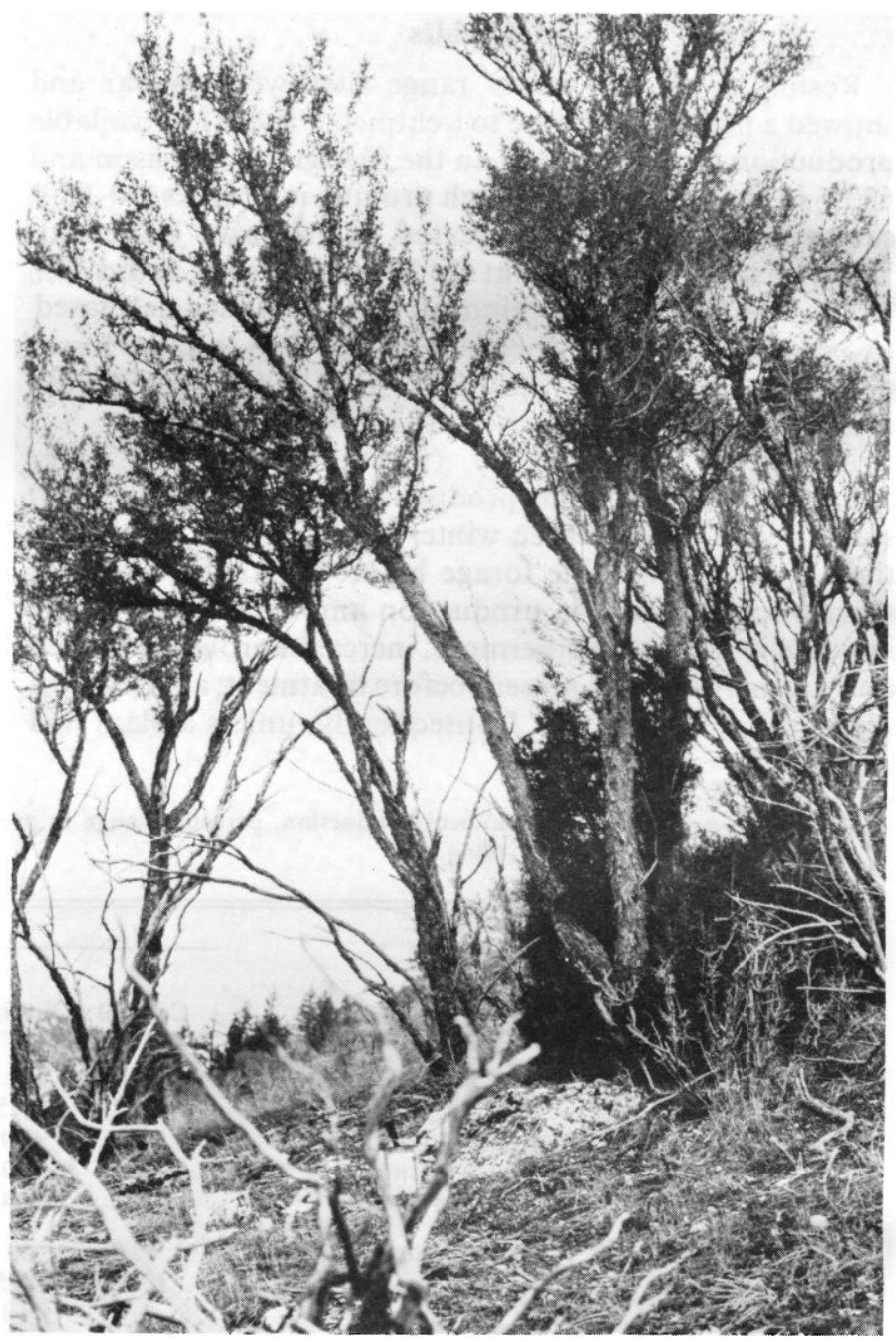

Fig. 1. Most of the forage produced by mature curlleaf mountain mahogany is beyond browsing reach of big game on winter ranges. 
$(2,440 \mathrm{~m})$. Each site was located on a west to northwest aspect with dry, steep slopes (40-60\%). Mean precipitation ranges from about $55 \mathrm{~cm}$ at the lower sites to $80 \mathrm{~cm}$ at the upper site and occurs mostly as snow in winter. Soils were derived from limestone parent material, having rocky silt-loam textures near the surface and increasing in clay content with depth. The summer range site with a deeper profile belonged to the Typic Haploxeroll soil subgroup, while winter range sites were Lithic Haploxerolls.

\section{Methods}

At each site 25 groups, each having 6-8 individual trees, were randomly selected and tagged. Ocular estimates of total production and forage available to big game were obtained and replicated twice. A third estimate was obtained if either set was not within $20 \%$ or $10 \mathrm{gm}$. The estimated means were then used. Plants were either pruned by hand saw at $2 \mathrm{~m}$ height and at intensities ranging from $0-100 \%$ foliage removal, or girdled at $2 \mathrm{~m}$ height. Half of all study trees had pruning paint applied to wound surfaces. Following treatment, weight estimates of the pruned trees were again obtained to determine foliage removed. Subsequent available production was estimated on all plants following the growing seasons in 1976 and 1977. All weights were converted to an oven-dry basis by use of dried samples.

Beginning in February, 1976, and monthly through January, 1977, foliage samples of combined leaves and twigs were hand collected at each site. Percent dry matter and crude protein were determined.

\section{Results}

Results from the winter range sites were similar and showed a positive response to treatment (Table 1). Available production increased $534 \%$ in the first growing season and $633 \%$ in the second under high pruning intensities (90-98\% canopy removal), but decreased as intensity decreased. However, all trees pruned at the $100 \%$ level died, as did $32 \%$ of those pruned at $99 \%$ removal. Mortality then decreased to $3 \%$ at pruning levels between 80 and $98 \%$, and no losses occurred at intensities below $80 \%$. Thus removal of $90-98 \%$ of the canopy produced the best response.

Although response to treatment was positive, quantitative increases in production were small. Since all study plants on the three winter range sites averaged less than $2 \mathrm{gm}$ of available forage before treatment, even the several-fold increase in production amounted to very little increase in forage. Furthermore, increased growth occurred only from live shoots present before treatment; adventitious sprouting did not occur. Consequently, unless a plant had

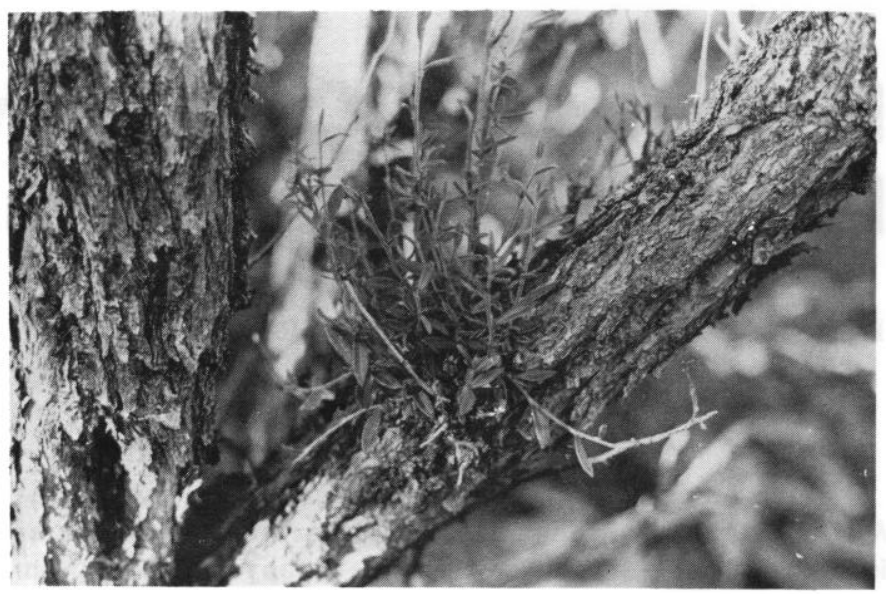

Fig. 2. Stimulated growth of curlleaf mountain mahogany within browsing height only occurred from live shoots present before treatment.

appreciable available forage before treatment, the benefit to big game was negligible.

The summer range site produced greater available forage (64 gm/ plant before treatment), and pruned plants showed a stronger response to pruning, which also decreased with intensity. Those plants pruned $90-98 \%$ showed an increase in available production of $593 \%$ or $337 \mathrm{gm} /$ plant in the first growing season and $1,317 \%$ or $837 \mathrm{gm}$ in the second year.

The response to girdling was poor. A meager increase of $24 \%$ occurred on the summer range site in the second year following treatment, while winter range sites showed a fair increase of $337 \%$.

Application of pruning paint to freshly cut or girdled plants had no effect on vegetative response. Indeed, excessive sap-flow as described by Thompson (1970) did not occur on our sites. Furthermore, failure of pruning paint to form a seal on cut branches probably would render that treatment ineffective in any case.

Percent crude protein was moderately high, showed small seasonal variation, and generally ranged between $9-11 \%$ (Table 2). Significantly, no decreases in protein levels were noted as winter progressed. This demonstrates the high forage value of this species, especially in late winter. Protein content was highest in April and May during the early growth period, and higher on the summer range site after June, probably because of the increase in available soil

Table 1. Mean available pretreatment production, percent change in production, and tree mortality of curlleaf mountain mahogany under various intensities of pruning and girdling.

\begin{tabular}{|c|c|c|c|c|c|c|c|c|c|c|c|}
\hline \multirow[b]{3}{*}{ Location } & \multirow[b]{3}{*}{ Year } & \multirow[b]{3}{*}{ Analysis } & \multicolumn{9}{|c|}{ Treatment } \\
\hline & & & \multirow[b]{2}{*}{ Control } & \multirow[b]{2}{*}{ Girdling } & \multicolumn{7}{|c|}{ Pruning Intensity (\%) } \\
\hline & & & & & $0-49$ & $50-69$ & $70-79$ & $80-89$ & $90-98$ & 99 & 100 \\
\hline \multirow[t]{4}{*}{$\begin{array}{l}\text { Winter Range } \\
\text { ( sites combined) }\end{array}$} & 1975 & Production (gm) & $\begin{array}{r}1.4 \\
(80)^{\mathrm{a}}\end{array}$ & $\begin{array}{r}2.2 \\
(75)\end{array}$ & $\begin{array}{r}0.8 \\
(63)\end{array}$ & $\begin{array}{r}1.1 \\
(53)\end{array}$ & $\begin{array}{r}0.6 \\
(49)\end{array}$ & $\begin{array}{r}0.9 \\
(71)\end{array}$ & $\begin{array}{r}2.8 \\
(63)\end{array}$ & $\begin{array}{r}3.3 \\
(29)\end{array}$ & $\begin{array}{r}0.0 \\
(69)\end{array}$ \\
\hline & 1976 & $\%$ Change & +79 & +192 & +321 & +521 & +543 & +289 & +534 & +889 & 0 \\
\hline & 1977 & $\%$ Change & +39 & +337 & +138 & +477 & +602 & +683 & +633 & 684 & \\
\hline & 1977 & $\%$ Mortality & 0 & 43 & 0 & 0 & 0 & 3 & 3 & 32 & 100 \\
\hline \multirow[t]{4}{*}{ Summer Range } & 1975 & Production (gm) & $\begin{array}{r}82.0 \\
(25)^{\mathrm{a}}\end{array}$ & $\begin{array}{l}60.4 \\
(25)\end{array}$ & $\begin{array}{l}83.4 \\
(26)\end{array}$ & $\begin{array}{l}94.7 \\
(13)\end{array}$ & $\begin{array}{l}69.3 \\
(10)\end{array}$ & $\begin{array}{l}86.5 \\
(11)\end{array}$ & $\begin{array}{l}28.0 \\
(35)\end{array}$ & $\begin{array}{l}5.0 \\
(4)\end{array}$ & $\begin{array}{l}0.0 \\
(2)\end{array}$ \\
\hline & 1976 & $\%$ Change & +8 & +11 & +49 & +125 & +276 & +345 & +593 & +917 & (2) \\
\hline & 1977 & $\%$ Change & +4 & +24 & +65 & +249 & +521 & +822 & +1317 & +3535 & 0 \\
\hline & 1977 & $\%$ Mortality & 0 & 0 & 0 & 0 & 0 & 0 & 0 & 25 & 100 \\
\hline
\end{tabular}


Table 2. Mean bimonthly percentage of crude protein (P) and dry matter (DM) contained in curlleaf mountain mahogany foliage (twigs and leaves combined) collected at four sites during 1976-1977.

\begin{tabular}{|c|c|c|c|c|c|c|c|c|}
\hline \multirow[b]{2}{*}{ Site } & \multicolumn{8}{|c|}{ Period } \\
\hline & & Feb.-Mar. & Apr.-May & June-July & Aug.-Sept. & Oct.-Nov. & Dec.-Jan. & Feb.-Mar. \\
\hline $\begin{array}{l}\text { Lower winter range } \\
(1,650 \mathrm{~m} \text { elevation })\end{array}$ & $\begin{array}{l}\mathrm{P} \\
\mathrm{DM}\end{array}$ & $\begin{array}{l}10.1 \\
56.8\end{array}$ & $\begin{array}{l}10.2 \\
54.4\end{array}$ & $\begin{array}{l}10.1 \\
50.4\end{array}$ & $\begin{array}{r}9.2 \\
53.1\end{array}$ & $\begin{array}{r}9.1 \\
56.4\end{array}$ & $\begin{array}{r}8.8 \\
55.5\end{array}$ & $\begin{array}{r}9.0 \\
56.1\end{array}$ \\
\hline $\begin{array}{l}\text { Lower winter range } \\
(1,820 \mathrm{~m} \text { elevation })\end{array}$ & $\begin{array}{l}\mathrm{P} \\
\mathrm{DM}\end{array}$ & $\begin{array}{r}9.7 \\
56.7\end{array}$ & $\begin{array}{l}11.7 \\
53.4\end{array}$ & $\begin{array}{r}8.6 \\
45.1\end{array}$ & $\begin{array}{r}8.9 \\
49.1\end{array}$ & $\begin{array}{r}9.2 \\
57.3\end{array}$ & $\begin{array}{r}9.0 \\
57.4\end{array}$ & $\begin{array}{r}9.5 \\
57.4\end{array}$ \\
\hline $\begin{array}{l}\text { Upper winter range } \\
(2.000 \mathrm{~m} \text { elevation })\end{array}$ & $\begin{array}{l}\text { P } \\
\text { DM }\end{array}$ & $\begin{array}{l}10.6 \\
57.5\end{array}$ & $\begin{array}{l}11.3 \\
55.8\end{array}$ & $\begin{array}{r}9.3 \\
49.1\end{array}$ & $\begin{array}{r}9.5 \\
53.3\end{array}$ & $\begin{array}{r}9.7 \\
54.1\end{array}$ & $\begin{array}{r}9.7 \\
55.1\end{array}$ & $\begin{array}{r}9.5 \\
57.0\end{array}$ \\
\hline $\begin{array}{l}\text { Summer range } \\
(2,440 \text { m elevation })\end{array}$ & $\begin{array}{l}\mathrm{P} \\
\mathrm{DM}\end{array}$ & $\begin{array}{l}10.1 \\
56.1\end{array}$ & $\begin{array}{l}10.6 \\
55.9\end{array}$ & $\begin{array}{l}10.5 \\
49.9\end{array}$ & $\begin{array}{l}10.9 \\
53.2\end{array}$ & $\begin{array}{l}10.6 \\
55.7\end{array}$ & $\begin{array}{l}10.0 \\
58.0\end{array}$ & $\begin{array}{l}10.5 \\
54.8\end{array}$ \\
\hline
\end{tabular}

water. Similarly, dry matter content showed remarkably little fluctuation during the year and generally ranged between $50-60 \%$. The smallest percent dry matter occurred at all four sites in June, near the end of the flowering period.

Although curlleaf mountain mahogany is a highly desirable shrub on winter ranges, it appears that pruning or girdling of mature stands, especially those having little available browse initially, would have slight practical value. Only where considerable browse is currently available would the benefits from pruning seem worthwhile. Furthermore, treated stands would require high yearly utilization to control stems from quickly growing beyond browsing reach and, even then, sustained production would be expected to substantially decline after the first or second year following treatment (Ferguson 1972).

As alternative management, mature stands could be used for emergency forage. We have observed that forage from pruned limbs or those broken by heavy snow was completely consumed. Thus during periods of low forage availability, due to deep snow or prolonged winter conditions, pruning could provide an emergency source of high quality forage.

\section{Literature Cited}

Bissell, H.D., and H. Strong. 1955. The crude protein variations in the browse diet of California deer. California Fish and Game 41: 145-155.

Brown, E.R., and C.E. Martinson. 1959. Browse planting for big game. Washington State Game Dep. Biol. Bull. 12. 13 p.

Dealy, J.E. 1971. Habitat characteristics of the Silver Lake mule deer range. U.S. Dep. Agr. Forest Serv. Res. Pap. PNW-125. 99 p.

Ferguson, R.B. 1972. Bitterbrush topping: shrub response and cost factors. U.S. Dep. Agr. Forest Serv. Res. Pap. INT-125. 11 p.

Ferguson, R.B., and J.V. Basile. 1966. Topping stimulates bitterbrush twig growth. J. Wildl. Manage. 30: 839-841.
Holmgren, R.C. 1954. A comparison of browse species for revegetation of big game winter range in southwestern Idaho. U.S. Dep. Agr. Interm. Forest and Range Exp. Sta. Res. Pap. 33. 12 p.

Hoskins, L.W., and P.D. Dalke. 1955. Winter browse on the Pocatello big game winter range in southeastern Idaho. J. Wildl. Manage. 19:215-225. Mitchell, G.F. 1951. Status of browse on ranges of eastern Oregon and eastern Washington. J. Range Manage. 4: 249-253.

Phillips, T. 1970. Summary report of curlleaf mahogany rehabilitation projects in Region 4. U.S. Dep. Agr. Forest Serv. Ogden, April 22, 1976. $10 \mathrm{p}$.

Plummer, A.P. 1974. Morphogenesis and management of woody perennials in the United States. In: Plant morphogenesis as the basis for scientific management of range resources. Proc. Workshop United States/Australia Rangelands Panel, Berkeley, Calif., March 29-April 5, 1971. U.S. Dep. Agr. Res. Serv. Misc. Pub. 1271, p. 72-80.

Plummer, A.P., D.R. Christensen, and B. Monsen. 1968. Restoring biggame range in Utah. Utah Div. Fish and Game Pub. 68-3. 183 p.

Plummer, A.P., R.L. Jensen, and H.D. Stapley. 1957. Job completion report for game forage revegetation project W-82-R-2. Utah State Dep. Fish and Game. 28 p.

Smith, A.D. 1950. Feeding deer on browse species during winter. J. Range Manage. 3: 130-132.

Smith, A.D. 1952. Digestibility of some native forages for mule deer. J. Wildl. Manage. 16: 309-312.

Smith, A.D. 1957a. Nutritive value of some browse plants in winter. J. Range Manage. 10: 162-164.

Smith, A.D. 1957b. Renovating overused deer winter range. Utah State Fish and Game Bull. 13: 6-7.

Smith, A.D., and R.L. Hubbard. 1954. Preference ratings for winter deer forages from northern Utah ranges based on browsing time and forage consumed. J. Range Manage. 7: 262-265.

Thompson, R.M. 1970. Experimental top pruning of curlleaf mountain mahogany trees on the South Horn Mountains, Ferron Ranger District, Manti-LaSal National Forest. U.S. Dep. Agr. Forest and Range Exp. Sta., Ogden, Utah. Range Improvement Notes 15(3): 1-12.

Young, J.A., R.A. Evans, and D.L. Neal. 1978. Treatment of curlleaf cercocarpus seeds to enhance germination. J. Wildl. Manage. 42: 614620 . 